\title{
The risk of breast cancer in women with a CHEK2 mutation
}

\author{
Cezary Cybulski", Dominika Wokołorczyk, Anna Jakubowska, Tomasz Huzarski, Tomasz Byrski, Jacek Gronwald, \\ Tadeusz Dębniak, Bohdan Górski, Steven A Narod, Jan Lubiński
}

From Annual Conference on Hereditary Cancers 2010

Szczecin, Poland. 10-11 December 2010

Mutations in CHEK2 predispose to a range of cancer types including breast cancer. A meta-analysis of all association studies estimated the risk of breast cancer among carriers of $1100 \mathrm{delC}$ to be increased by 2.7 -fold (9) and increased by 4.7 -fold among carriers with a positive family history of breast cancer (Weischer $\mathrm{M}$ et al. CHEK2*1100delC genotyping for clinical assessment of breast cancer risk: meta-analysis of 26,000 patients cases and 27,000 controls. J Clin Oncol 2008; 26: 542-548). We estimated the risk of breast cancer in a woman who has a CHEK2 mutation depending on her family history of breast cancer. Out data suggest that carriers of a truncating mutation of CHEK2 (IVS2+1G>A, del5395, 1100delC) have 2.9 - fold increased risk of breast cancer in the Polish population. The risk was higher for women with at least one first-degree relative with breast cancer $(\mathrm{OR}=4.5)$, and for women with at least one seconddegree relative with breast cancer $(\mathrm{OR}=3.5)$. If both a first- and second-degree relative was affected with breast cancer, the odds ratio was 6.4. We estimate the lifetime risks for carriers of CHEK2 truncating mutations to be from 21 to $37 \%$ depending family history of breast cancer in first- and second degree relatives. CHEK2 mutation screening detects a clinically meaningful risk of breast cancer.

Published: 12 January 2012

doi:10.1186/1897-4287-10-S1-A5

Cite this article as: Cybulski et al:: The risk of breast cancer in women

with a CHEK2 mutation. Hereditary Cancer in Clinical Practice 201210

(Suppl 1):A5

* Correspondence: cezarycy@sci.pam.szczecin.pl

International Hereditary Cancer Center, Department of Genetics and

Pathology, Pomeranian Medical University, Szczecin, Poland
Submit your next manuscript to BioMed Central and take full advantage of:

- Convenient online submission

- Thorough peer review

- No space constraints or color figure charges

- Immediate publication on acceptance

- Inclusion in PubMed, CAS, Scopus and Google Scholar

- Research which is freely available for redistribution

Submit your manuscript at www.biomedcentral.com/submit
() Biomed Central
C Biomed Central

(c) 2012 Cybulski et al; licensee BioMed Central Ltd. This is an open access article distributed under the terms of the Creative Commons Attribution License (http://creativecommons.org/licenses/by/2.0), which permits unrestricted use, distribution, and reproduction in any medium, provided the original work is properly cited. 